\title{
Capsule Commentary on Zueger et al., Older Medicare Beneficiaries Frequently Continue Medications with Limited Benefit Following Hospice Admission
}

Rebecca Berger, M.D.

Department of Medicine, Weill Cornell Medicine, New York, NY, USA.

which contribute to pill burden and expose the patient to unnecessary side effects, should be a focus of end-of-life care.

Corresponding Author: Rebecca Berger, M.D.; Department of MedicineWeill Cornell Medicine, New York, NY, USA (e-mail: reb9095@med.cornell.edu).

\section{Compliance with Ethical Standards:}

Conflict of Interest: The author declares that she does not have a conflict of interest.

\section{REFERENCES}

the value of medications relative to a patient's life expectancy. In this cohort, anti-dementia medications were more likely to be continued than other medications. Families experience difficulty stopping these medications, ${ }^{2}$ possibly due to their perceived impact on cognition, memory, and personality. Anti-hyperlipidemics were among the least likely to be continued. Their benefit is almost exclusively long-term; in one study, few patients with lifelimiting illness had concerns about discontinuing statins. ${ }^{3}$ While the authors excluded patients who may benefit from LBMs, such as continuation of an anti-hyperlipidemic after recent myocardial infarction or stroke, the list of exclusions was not comprehensive; for some patients it may be appropriate to continue medications that are of limited benefit to the general hospice population.

This study adds to existing literature that suggests that we may overtreat patients at the end of life. ${ }^{4,5}$ Avoiding medications which are unlikely to provide symptomatic benefit,

Publisher's Note Springer Nature remains neutral with regard to jurisdictional claims in published maps and institutional affiliations.
1. Zueger PM, Holmes HM, Calip GS, Qato DM, Pickard S, Lee TA. Older Medicare Beneficiaries Frequently Continue Medications with Limited Benefit Following Hospice Admission. J Gen Intern Meed. https://doi. org/10.1007/s11606-019-05152-x.

2. Shega JW, Ellner L, Lau DT, Maxwell TL. Cholinesterase Inhibitor and NMethyl-D-Aspartic Acid Receptor Antagonist Use in Older Adults with EndStage Dementia: A Survey of Hospice Medical Directors. J Palliat Med. 2009; 12(9):779-783. https://doi.org/10.1089/jpm.2009.0059.

3. Tjia J, Kutner JS, Ritchie CS, et al. Perceptions of Statin Discontinuation among Patients with Life-Limiting Illness. J Palliat Med. 2017;20(10):1098-1103. https://doi.org/10.1089/jpm.2016.0489.

4. Todd A, Husband A, Andrew I, Pearson S-A, Lindsey L, Holmes H. Inappropriate prescribing of preventative medication in patients with lifelimiting illness: a systematic review. BMJ Support Palliat Care. 2016;7(2):113-121. https://doi.org/10.1136/bmjspcare-2015-000941.

5. Tjia J, Briesacher BA, Peterson D, Liu Q, Andrade SE, Mitchell SL. Use of Medications of Questionable Benefit in Advanced Dementia. JAMA Intern Med. 2014;174(11):1763. https://doi.org/10.1001/jamainternmed.2014.4103. 